\title{
Geographic Variation in Camouflage Specialization by a Decorator Crab
}

John J. Stachowicz ${ }^{1, *}$ and Mark E. Hay ${ }^{2}$

1. Department of Marine Sciences, University of Connecticut, Groton, Connecticut 06340; and Institute of Marine Sciences, University of North Carolina, Morehead City, North Carolina 28557;

2. School of Biology, Georgia Institute of Technology, Atlanta, Georgia 30332-0230

Submitted February 5, 1999; Accepted February 9, 2000

A BSt RACT: In North Carolina, the decorator crab Libinia dubia camouflages almost exclusively with the chemically noxious alga Dictyota menstrualis. By placing this alga on its carapace, the crab behaviorally sequesters the defensive chemicals of the plant and gains protection from omnivorous consumers. However, Dictyota is absent north of North Carolina, whereas Libinia occurs as far north as New England. Crabs from three northern locations where Dictyota is absent (Rhode Island, Connecticut, and New Jersey) camouflaged to match their environment, rather than selectively accumulating any one species. When D. menstrualis was offered to crabs from northern sites, they did not distinguish between it and other seaweeds for camouflage, whereas crabs from Alabama and two locations in North Carolina used D. menstrualis almost exclusively. In addition, in winter and spring, when Dictyota was seasonally absent in North Carolina, $\mathrm{Li}$ binia selectively camouflaged with the sun sponge Hymeniacidon heliophila, which was chemically unpalatable to local fishes. Thus, southern crabs were consistent specialists on chemically defended species for camouflage, while northern crabs were more generalized. The geographic shift in crab behavior away from specialization coincides with a reported decrease in both total predation pressure and the frequency of omnivorous consumers. These shifts in the nature and intensity of predation pressure may favor different camouflage strategies (generalist vs. specialist), contributing to the observed geographic differences in camouflage behavior.

Keywords: decorator crabs, geographic comparison, intraspecific variation, local specialization, plant-herbivore interactions, seaweeds.

\footnotetext{
* Present address: Section of Evolution and Ecology, University of California, Davis, California 95616; e-mail: jjstachowicz@ucdavis.edu.

Am. Nat. 2000. Vol. 156, pp. 59-71. (c) 2000 by The University of Chicago. 0003-0147/2000/15601-0005\$03.00. All rights reserved.
}

It has been argued that the ecological and evolutionary importance of positive interactions among species has been underappreciated by most biologists (Kareiva and Bertness 1997). While many factors likely contribute to this bias (Boucher et al. 1982; Bertness and Callaway 1994), part of the reason for the modest attention given to the role of mutualism and other positive associations may be that the nature and strength of these interactions can be highly variable. Mutualisms that moderate local biotic or abiotic stresses may become commensal, and commensalisms may become antagonistic when those stresses are relaxed (e.g., Palumbi 1985; Hay 1986; Bronstein 1994; Bertness and Leonard 1997; Holzapfel and Mahall 1999; Stachowicz and Hay 1999a). Although many biologists recognize that biotic interactions vary in outcome with local conditions, few studies examine how these changes may alter species' behaviors and evolution over geographic scales. Such studies of geographic variation may serve as a "lens" through which many important ecological and evolutionary questions can be profitably examined (Travis 1996).

As an example, geographic variation in the outcome of interspecific interactions is thought to be important to the evolution of specialization (Thompson 1994). Studies of plant-insect interactions have demonstrated that conspecific populations differ in the extent to which they specialize; some populations become highly specialized for the interactions as others remain or become less specialized (e.g., Janzen 1973; Rickson 1977; Whitham 1983; Abrahamson et al. 1989; Steiner and Whitehead 1990; Tauber et al. 1995). In particular, populations that fall outside the geographic range of the other species may exhibit few of the morphological or behavioral traits that enhance the association (Janzen 1973; Rickson 1977). While it is easy to envision how this scenario may apply for associations involving poorly dispersed organisms or physically separated populations, local adaptation is predicted to be far less common in marine systems because they are generally more open and because larval and adult stages of many species disperse widely (Jablonski 1986; Scheltema 1986; Palumbi 1992). Although 
geographic differences in allozyme frequencies or mitochondrial DNA sequences within species have been demonstrated in a variety of marine invertebrates with pelagic larvae (e.g., Avise 1992), geographic variation in behavioral traits relevant to the outcome of interspecific interactions is poorly known.

Specialized positive associations are known among many marine invertebrates with pelagic dispersal phases (Steneck 1982; Glynn 1987; Littler et al. 1995; Stachowicz and Hay $1999 a, 1999 c)$. These specialized positive interactions may be critical to the maintenance of marine communities through their positive effects on producers of biogenic structure such as corals or calcified seaweeds (Glynn 1987; Littler et al. 1995; Stachowicz and Hay 1996, $1999 a)$. Could local specialization play a role in the origin and maintenance of these commensal and mutualistic associations, or does the high dispersal potential of these marine species preclude such responses to local selection? Just as the study of geographic variation in host-plant preferences has increased our understanding of the basis of the evolution of specialization and coevolution among insects and plants (e.g., Thompson 1994; Abrahamson and Weis 1997), a fuller understanding of variation in specialized marine interactions could enhance our ability to predict the circumstances under which these associations arise and come to play an important role in marine communities.

In this study, we examine spatial and temporal variation in the associational defense employed by the decorator crab Libinia dubia along the east coast of the United States. In North Carolina, Libinia is known to enter into a specialized association with the chemically noxious seaweed Dictyota menstrualis (Stachowicz and Hay $1999 c$ ). In this association, the crab escapes predation by placing the alga on its carapace as camouflage, behaviorally sequestering the alga's defensive chemicals. However, the crab and alga do not have completely overlapping ranges, and it is currently unknown whether crabs outside the range of the preferred host specialize on other defended algae, generalize in an attempt to blend into the background, or cease decorating altogether. Our results demonstrate that although all populations of Libinia do camouflage with seaweeds or sessile invertebrates, the nature and specificity of camouflage preferences differ greatly between northern and southern populations in the western North Atlantic. Because these behavioral shifts are coincident with both quantitative and qualitative latitudinal gradients in predation pressure, we suggest that local differences in selection by predators may contribute to these differences in behavior.

\section{Methods \\ Organisms and Study Sites}

The decorator crab Libinia dubia (Decapoda, Majidae) occurs from the Gulf of Mexico to southern New England in sounds and saltier estuaries (Williams 1984). As with several other species of majid crabs (e.g., Kilar and Lou 1986), juveniles of the species "decorate" their carapace with materials from the surrounding environment, presumably as a defense against predators. Juveniles in North Carolina selectively camouflage with the chemically noxious seaweed Dictyota menstrualis; crabs decorated with this alga experience less predation in the field than crabs decorated with a common seaweed that is not chemically defended from omnivorous consumers (Stachowicz and Hay 1999 c). The crabs prefer D. menstrualis over all other seaweeds, and this preference is cued by the diterpene alcohol dictyol E (Stachowicz and Hay 1999c), a metabolite specific to D. menstrualis that deters feeding by omnivorous fishes (Hay et al. 1987, 1988; Cronin and Hay 1996), which prey on both seaweeds and crustaceans. This alga occurs from southern Virginia south to the Gulf of Mexico and throughout the Caribbean (Schneider and Searles 1991). Thus, although the two species co-occur over a large portion of their range, northern populations of Libinia do not co-occur with Dictyota.

We collected Libinia from six locations along the east coast of the United States: Mobile Bay, Alabama $\left(30^{\circ} 13^{\prime} \mathrm{N}\right.$, $\left.68^{\circ} 02^{\prime} \mathrm{W}\right)$; Mitchell Village, North Carolina $\left(34^{\circ} 44^{\prime} \mathrm{N}\right.$, $\left.76^{\circ} 50^{\prime} \mathrm{W}\right)$; Drum Shoal, North Carolina $\left(34^{\circ} 43^{\prime} \mathrm{N}\right.$, $\left.76^{\circ} 45^{\prime} \mathrm{W}\right)$; Little Egg Harbor and Great Bay, New Jersey $\left(39^{\circ} 30^{\prime} \mathrm{N}, 74^{\circ} 20^{\prime} \mathrm{W}\right)$; Noank, Connecticut $\left(41^{\circ} 19^{\prime} \mathrm{N}\right.$, $\left.72^{\circ} 59^{\prime} \mathrm{W}\right)$; and Narragansett, Rhode Island $\left(41^{\circ} 25^{\prime} \mathrm{N}\right.$, $\left.71^{\circ} 27^{\prime} \mathrm{W}\right)$. The Alabama site, at the inlet to Mobile Bay, was deeper $(5.0 \mathrm{~m})$ and more turbid than any of the other sites, and it supported few sessile benthic organisms. The North Carolina sites were shoals comprised of a series of sea grass and algal beds, ranging in depth from 0.5 to 1.0 $\mathrm{m}$ in Bogue Sound, North Carolina, near the University of North Carolina's Institute of Marine Sciences. The New Jersey sites, near the Rutgers University Marine Station in Tuckerton, New Jersey, consisted of algal flats that ranged in depth from 1.5 to $2.0 \mathrm{~m}$. The Connecticut site was at the former University of Connecticut Marine Lab in Noank and consisted primarily of invertebrate-encrusted pilings and rocks that ranged in depth from just subsurface to $3.0 \mathrm{~m}$. The Rhode Island site was located adjacent to the Narragansett town pier, in 1.0-2.5 m deep water with algal-covered gravel and cobbles. All water depths are heights above the bottom at low tide. A more detailed characterization of the sessile benthos of these sites is given in the "Results." 


\section{Geographic Variation in Crab Behavior}

We assessed which materials Libinia selects for camouflage in the field by collecting crabs at different sites and comparing the composition and wet mass of their camouflage with the wet mass of seaweeds and sessile invertebrates available at each site. We could not assess camouflage preferences in the field in Alabama because crabs collected there had no camouflage and the site lacked sessile benthos that might have served as material for camouflage. However, decorated crabs have been collected at this site during other times of the year (K. Heck and J. Valentine, personal communication), so we did use individuals from this site in laboratory camouflage-preference assays (see below). At the Mitchell Village site in North Carolina, we collected crabs by manually dragging a net $(0.5-\mathrm{cm}$ mesh size) through sea grass beds. The total area searched was $\sim 100 \times 10 \mathrm{~m}$. Crabs were returned to the lab, where camouflage material was removed, blotted dry with a paper towel, and weighed to the nearest $1 \mathrm{mg}$. We estimated the availability of camouflage materials by collecting and weighing (wet) all seaweeds and sessile invertebrates in haphazardly located $1.0-\mathrm{m}^{2}$ quadrats $(N=10)$ from the site where the crabs were collected. In New Jersey, water depth and muddy sediments prohibited manual deployment of a net, so we collected crabs in a $1.0-\mathrm{m}$ beam trawl $\left(0.5-\mathrm{cm}\right.$ mesh size) dragged behind a boat at $5 \mathrm{~km} \mathrm{~h}^{-1}$ for $2 \mathrm{~min}$. The total area sampled per trawl was thus $\sim 167$ $\mathrm{m}^{2}$, and a total of 10 trawls were made. Algae and sessile invertebrates from each trawl were collected, sorted, and weighed (wet) to determine the relative availability of these for camouflage. Crabs at both the Connecticut and Rhode Island sites were sufficiently abundant to be collected by scuba divers. All crabs in haphazardly located $1.0-\mathrm{m}^{2}$ quadrats were collected along with the benthic flora and fauna within the quadrat. At each site, we compared the relative abundance of each sessile organism in the field with its relative abundance as camouflage (percentage of total wet mass) using unpaired $t$-tests. Arcsine transformations were used to achieve homogeneity of variances where necessary, and where these transformations were unsuccessful, nonparametric Mann-Whitney $U$-tests were employed. Surveys were performed at all sites during late summer (August-September).

Crabs collected from all sites were transported to the Institute of Marine Sciences in Morehead City, North Carolina, where we assessed their feeding and camouflage preferences by offering them a simultaneous choice of the same eight species of seaweeds. All the seaweeds used occur in shallow waters of North Carolina in the early summer through at least late fall: the green alga Ulva rigida; the brown algae Sargassum filapendula, Padina gymnospora, $D$. menstrualis, and Dictyota ciliolata; and the red algae Hyp- nea musciformis, Chondria dasyphylla, and Gracilaria tikvahiae. We stripped each crab of existing camouflage and placed it in a 0.5-L bowl ( $N=6-19$ for each population) with four 1-cm-diameter holes to allow for flow-through seawater. Each bowl with a crab held a $150 \pm 25-\mathrm{mg}$ piece (blotted wet mass) of all eight seaweed species (i.e., a choice assay). As a control for changes in seaweed mass unrelated to herbivory or camouflaging, identical bowls without crabs contained same-sized pieces of the same species of seaweed. Within each replicate, treatment and control pieces of algae were taken from the same algal thallus. After 38-42 h, each piece of alga was blotted dry with a paper towel and reweighed; camouflage was then removed from crabs and weighed. Assays were conducted during late summer and early fall (August-October).

To calculate net mass loss for each algal species due to crab feeding, we corrected for mass changes unrelated to herbivory using the formula $\left(T_{\mathrm{i}} \times\left[C_{\mathrm{f}} / C_{\mathrm{i}}\right]\right)-\left(T_{\mathrm{f}}+D\right)$, where $T_{\mathrm{i}}$ and $T_{\mathrm{f}}$ are the initial and final masses of the seaweed portion in the container with a crab, $C_{\mathrm{i}}$ and $C_{\mathrm{f}}$ are the initial and final masses of the seaweed portion in the paired-control container, and $D$ is the amount of the seaweed used as camouflage. Crabs never consumed, or used as camouflage, $100 \%$ of any of the choices, so use of an alga as camouflage did not make that alga unavailable for consumption, and vice versa. We used one-way ANOVA to assess whether the total amount of algae used for feeding or decoration differed among sites, then assessed whether crabs within a site made choices among the various algal species offered for food and decoration using the nonparametric Friedman's two-way test on ranked data.

\section{Seasonal Variation in Decoration in North Carolina}

During the cooler months (January-May), the upright, macroscopic form of $D$. menstrualis used by Libinia for camouflage is absent from North Carolina, although the species persists microscopically (Richardson 1979). Field and laboratory decoration preferences of Libinia from the Mitchell Village site were assessed during this period to gain insight into whether these crabs are inherent specialists or whether they revert to more generalized behavior when their preferred camouflage is unavailable. Field and lab methods were identical to those for the geographic survey described previously. The dominant sessile-benthic organisms at this time of year included the sun sponge Hymeniacidon heliophila; the bryozoan Bugula neritina; and the seaweeds Hypnea, Gracilaria, Ulva, and Agardhiella subulata.

Because crabs selectively accumulated Hymeniacidon in these cooler months and because previous work has demonstrated that selective decoration with Dictyota provides 

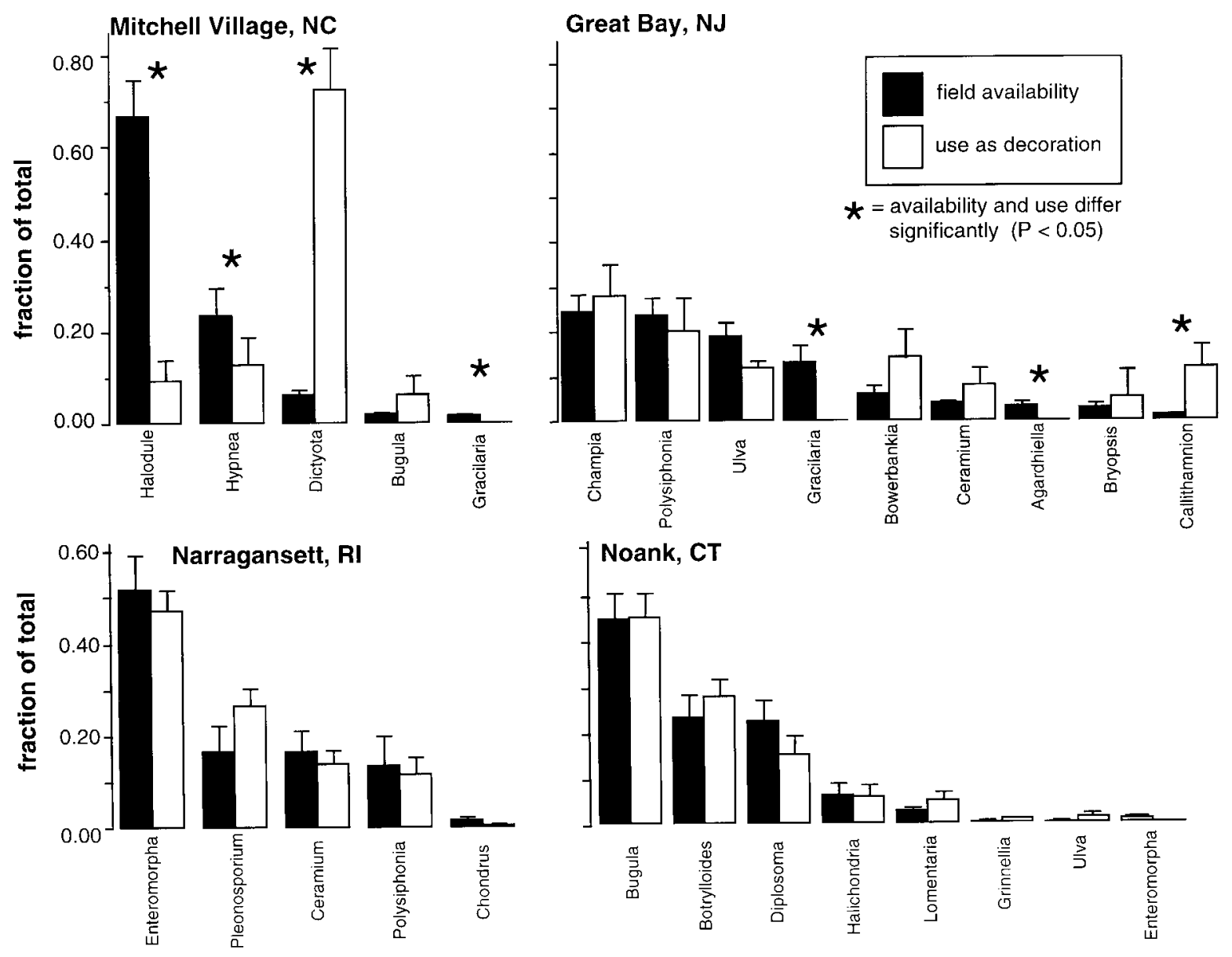

Figure 1: Camouflage availability (black bars) and use (white bars) by juvenile Libinia dubia at three locations north of the known range of Dictyota menstrualis (Rhode Island, Connecticut, and New Jersey) and one location within the range of this alga (North Carolina). Values are mean relative abundances, and error bars represent 1 SE. Statistically significant differences in the relative abundance of availability and use $(P<.05$, unpaired $t$-tests or Mann-Whitney $U$-test) are indicated by an asterisk.

a refuge from predation due to its chemical unpalatability (Stachowicz and Hay 1999c), we examined Hymeniacidon to see if it also might be chemically deterrent to potential crab predators. We compared pinfish consumption of bitesized pieces of sponge, artificial food pellets containing sponge extracts at natural concentration, and control artificial food pellets. Detailed procedure for extraction and bioassay can be found in Stachowicz and Lindquist (1997).

\section{Results}

\section{Geographic Variation in Specialization}

Libinia dubia from New Jersey, Connecticut, and Rhode Island exhibited few strong camouflage preferences in the field, while those from North Carolina exhibited a strong preference (fig. 1). In the summer, Mitchell Village, North
Carolina, crabs preferentially accumulated Dictyota menstrualis, which on average made up $75 \%$ of their total camouflage, despite the fact that Dictyota made up only $6 \%$ of the total wet mass of available camouflage material in the field (significantly different by paired $t$-test, $P<$ .0001 ). It was the dominant species used by 11 out of 14 individuals. These crabs avoided decorating with seaweeds like Hypnea and Gracilaria $(P<.0001$ and $P=.030$, respectively) that are palatable to omnivorous fishes (Hay et al. 1987, 1988; Stachowicz and Hay 1999a, 1999c) and used the bryozoan Bugula neritina infrequently, but in proportion to its availability $(P=.354)$. They also avoided camouflaging with the sea grass Halodule, the most abundant potential camouflage material in the field (fig. 1; $P<.0001)$. There was no significant correlation between the availability of a camouflage material and its use by crabs from North Carolina $(N=5, r=-0.20, P=.775)$. 
While crabs from North Carolina preferentially decorated with one alga that was relatively rare, crabs from more northern populations camouflaged to match their surroundings. For crabs from each of the northern populations, the average amount of each species used for decoration was positively correlated with its abundance in the field (Rhode Island: $N=5, r=0.90, P=.010$; Connecticut: $N=6, r=0.97, P<.0001$; New Jersey: $N=9, r=0.67$, $P=.045)$. In New Jersey, six of the nine seaweeds or invertebrates co-occurring with Libinia were used for camouflage in proportions not different from their field abundance $(P>.05$, fig. 1). Two species (Gracilaria tikvahiae and Agardhiella subulata) were avoided relative to their abundance in the field $(P=.002$ and $P=.007$, respectively). These two species were never used as camouflage, possibly because their thalli were relatively broad and thick and may not fit among the hooked setae that hold camouflage on a crab's carapace. Only one species (Callithamnion corymbosum) in New Jersey was used more frequently by crabs than its abundance in the field would predict $(P=.028)$. However, we probably undersampled the relative availability of this alga in the field. Individuals of this species are small, and most of them may have passed through the mesh in our trawl. Regardless, this species made up on average only $12 \%$ of the total camouflage and was never the most abundant camouflage material on an individual crab. In both Rhode Island and Connecticut, Libinia used all species in proportions not different from their availability $(P>.05$; fig. 1$)$. At Noank, Connecticut, both the benthic community and the composition of the crabs' camouflage were dominated by colonial invertebrates, particularly the bryozoan Bugula turrita, the ascidians Botrylloides diegensis, and Diplosoma macdonaldi. In Rhode Island, both crabs' carapaces and the substrate supported a community of ephemeral green and filamentous red algae, dominated by Enteromorpha intestinalis, Pleonosporium borreri, and species in the genera Ceramium and Polysiphonia, which were not distinguished to the species level.

Crabs from different sites did not differ in the total mass of camouflage used in laboratory choice assays (one-way ANOVA, $F=1.42$, df $=5,80, P=.225$ ), but the composition of this camouflage differed dramatically among populations (fig. 2). Dictyota menstrualis made up most of the camouflage on crabs from the two North Carolina sites and from Alabama (76\%, 83\%, and 82\%, respectively) but was used significantly less frequently by crabs from New Jersey (32\%), Connecticut (12\%), and Rhode Island (13\%; one-way ANOVA on the percentage of the total camouflage comprised by Dictyota: $F=17.8$, df $=5,80, \quad P<.0001$; means comparisons made using the Tukey-Kramer procedure). Seaweeds other than D. menstrualis were used only rarely by North Carolina and Alabama crabs. In con- trast, analysis of decoration preferences among crabs within northern populations showed that New Jersey crabs used Hypnea musciformis and Dictyota ciliolata at levels not different from D. menstrualis (26\% and $40 \%$, respectively, $P>.05$, Friedman's test; fig. 2). Connecticut crabs preferred Hypnea over D. menstrualis; Rhode Island crabs preferred Ulva to D. menstrualis $(P<.05$, Friedman's test; fig. 2). Thus, the variation in decoration behavior appeared to have a geographic basis; crabs from North Carolina and Alabama sites strongly preferred D. menstrualis for camouflage over all other species, whereas crabs from outside the range of this alga used other species just as readily (or even more readily) than they used $D$. menstrualis. Crabs from all sites generally rejected Gracilaria, Padina, and Sargassum as decoration during the summer months.

Crabs from all sites showed distinct feeding preferences among algal species (fig. 3). These differences were statistically significant $(P<.0001$, Friedman's test $)$ for all sites where replication was adequate to allow analyses. For Mobile Bay, the number of crabs $(N=6)$ was lower than the number of choices offered (eight species of seaweed), precluding statistical analysis. Hypnea and Ulva were readily eaten by crabs from all sites. Gracilaria was heavily consumed by North Carolina and Rhode Island crabs, whereas Chondria ranked more highly among Connecticut, New Jersey, and Alabama crabs. Libinia from both sites in North Carolina showed similar overall trends but a reversal of preference among the two most preferred algae (Ulva and Hypnea). Although all populations exhibited feeding preferences, there were no clear geographic differences in preferences: D. menstrualis was low preference and $H$. musciformis was relatively high preference for all populations.

\section{Seasonal Variation in Specialization}

In the late spring, before Dictyota's becoming apparent in North Carolina grass beds, Libinia preferentially decorated with the sun sponge Hymeniacidon heliophila (fig. 4), although the crabs' preference for this species was not as strong as for Dictyota in the summer (fig. 1). This sponge made up only $6 \%$ of organisms in the field yet made up $46 \%$ of Libinia's camouflage ( $P<.0001$, unpaired $t$-test). Libinia also frequently decorated with Hypnea (25\%) and Ceramium (13\%), but both these seaweeds were used in proportions that did not differ from their abundance in the field (fig. 4). In contrast, the green alga Ulva was strongly avoided, as it made up $<1 \%$ of the total camouflage but made up 33\% of the mass of organisms found in the field. In lab assays in which crabs were given equal amounts of six species as potential decorating materials, the sun sponge made up $67 \%$ of the total camouflage, 


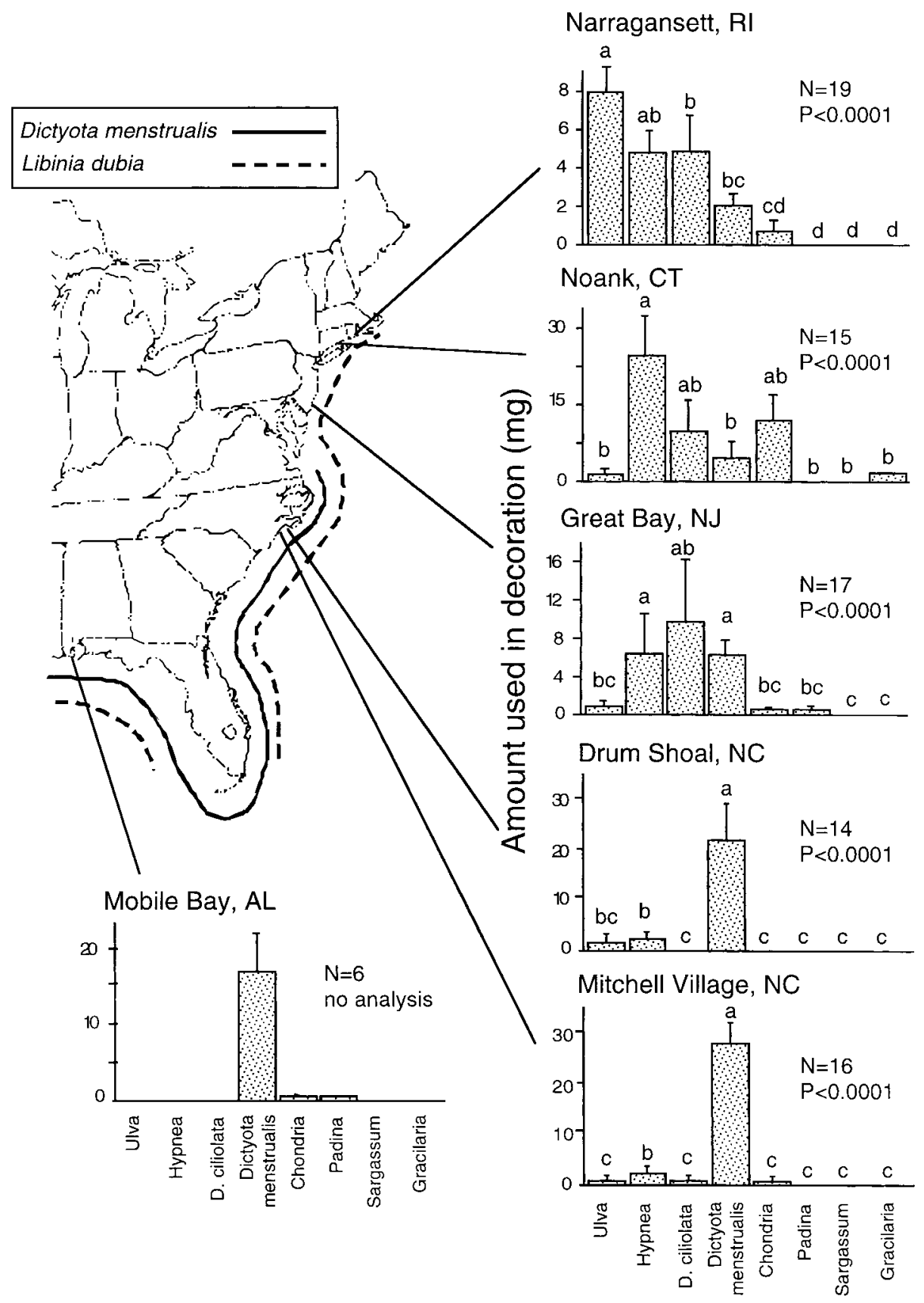

Figure 2: Use of North Carolina seaweeds for camouflage $(\bar{X}+1 \mathrm{SE})$ by Libinia dubia from six locations along the east coast of the United States. The range of occurrence of $L$. dubia and Dictyota menstrualis are given for comparison. Statistical analyses were by the Friedman's test; letters indicate significant $(P<.05)$ differences among species in use for camouflage. Analyses not done for Mobile Bay population due to insufficient replication relative to the number of algal choices.

significantly more than any other species (Friedman's test multiple comparisons, $P<.05$; fig. 5). Crabs also decorated with Hypnea and Gracilaria in the lab but did so in much lower amounts $(20 \%$ and $12 \%$, respectively). The sun sponge was chemically unpalatable to fishes $(P<.0001$; fig. 6 ), suggesting that the crabs' preference for this animal as decoration when Dictyota is absent may be a consequence of its chemical unpalatability to potential crab predators. 


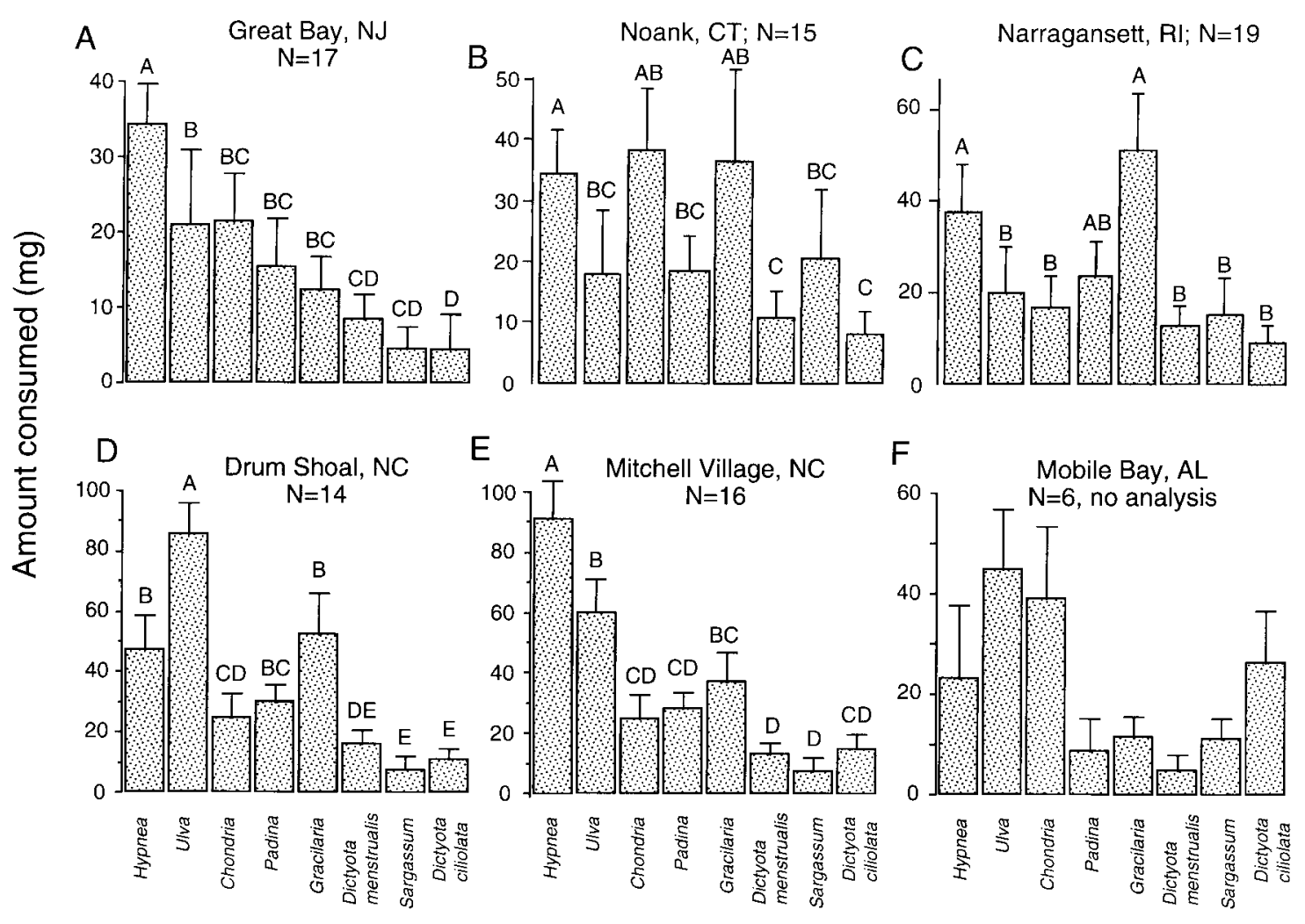

Figure 3: Use of North Carolina seaweeds for food by Libinia dubia from six locations along the east coast of the United States. Statistics and symbols are as in figure 2.

\section{Discussion}

Despite the fact that Libinia has a planktonic larval phase that could promote homogeneity within the species, our results demonstrate significant geographic variation in the decoration behavior of this crab. Where Dictyota menstrualis occurs (North Carolina and Alabama), crabs strongly prefer this alga for camouflage, whereas crabs collected outside the range of this alga (Rhode Island, Connecticut, New Jersey) use most camouflage materials in proportion to their abundance in the field. This is not simply a facultative shift in behavior from specialist to generalist due to the absence of the preferred species. When crabs from northern sites were offered D. menstrualis, they did not prefer it over other algae, including those like Hypnea and Ulva that are palatable to potential crab predators. Further, when Dictyota became seasonally unavailable in North Carolina, crabs there specialized on another chemically defended organism for camouflage (the sun sponge Hymeniacidon heliophila; figs. 4, 6). Unfortunately, we were unable to determine whether the defensive metabolites from the sponge also stimulate camou- flaging by crabs because these compounds are water soluble (fig. 6) and would dissolve from test surfaces before crabs could make a choice. Regardless, it appears that the northern populations are differentiated from the Alabama and North Carolina populations with respect to camouflage behavior; southern populations consistently decorate with chemically defended materials, whereas northern crabs adopt a strategy of background matching.

Although among-population differences in preference for Dictyota could be the result of learning or past experience, this seems unlikely because mistakes during the learning process would greatly increase mortality (Stachowicz and Hay 1999c), and crabs from the turbid waters of Mobile Bay, Alabama, did not have direct contact with D. menstrualis, yet they still exhibited extreme preference for this alga when offered it in choice assays (fig. 2), suggesting that the preference is "hardwired" among southern populations and not induced by the presence of Dictyota. However, our data are only suggestive of genetic differentiation as a mechanism for the observed differences in behavior between geographic regions. More conclusive 


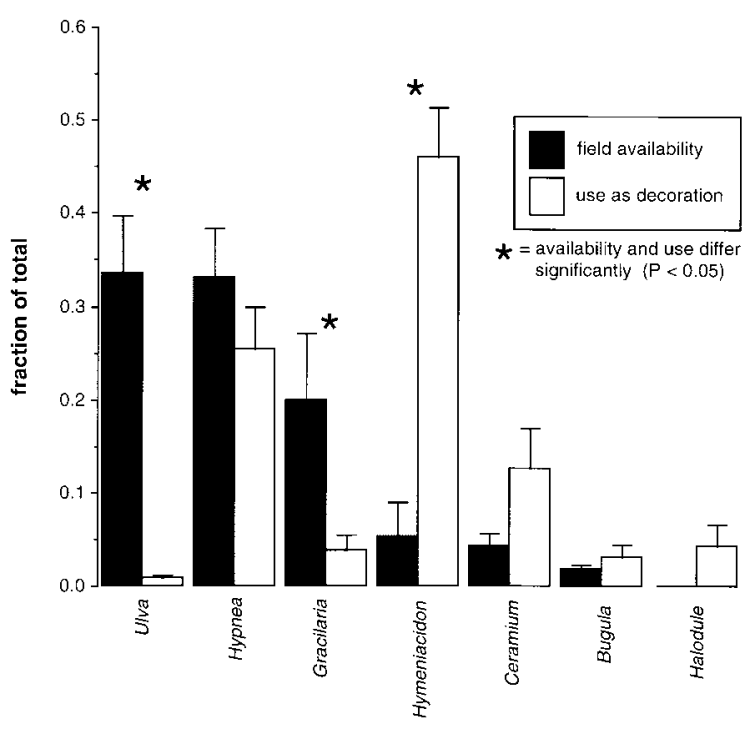

Figure 4: Field decoration patterns of Libinia dubia at Mitchell Village, North Carolina, in May, before Dictyota menstrualis became apparent in these habitats. Analyses and symbols as in figure 1.

support would require raising crabs from several different populations in the presence and absence of D. menstrualis, then assessing decorating preferences among the offspring. Such experiments have been conducted with herbivorous amphipods and show a genetic link to algal preferences based in part on plant chemistry (E. Sotka and M. Hay, unpublished data).

In contrast to the marked cline in decoration preferences, there are few geographic differences in choice of plants for food, as Libinia from all sites exhibit generalized feeding preferences for several red and green seaweeds. Avoidance of brown algae as food by Libinia is most likely due to the production of chemical feeding deterrents by these species (Stachowicz and Hay 1999a, 1999b), although the leathery texture of some brown algae (e.g., Sargassum) could also play a role. We did not address the reasons for the limited differences among populations in food choice, but intraspecific variability in both herbivore preference and seaweed chemical composition (nutritional value, defensive chemicals) may play a role (Renaud et al. 1990; Cronin and Hay 1996).

\section{Association of Geographic Variation in Decoration with Variation in Predation Pressure}

Because specialization by Libinia on D. menstrualis allows the crab to significantly reduce susceptibility to predation in the field (Stachowicz and Hay 1999c), it seems plausible that geographic variation in this behavior could be due to coincident variation in predation pressure. A decrease in predation pressure with increasing size through ontogeny may explain why adult Libinia do not decorate (Stachowicz and Hay 1999c) and why other animals abandon antipredator tactics as they grow in size (e.g., Pennings 1990). Predation pressure on marine invertebrates generally declines with increasing latitude (Bertness et al. 1981; Menge and Lubchenco 1981), and more specifically, predation rates on crabs are lower in the northern portion of the range of Libinia dubia than further south (Heck and Wilson 1987). Although current predation regimes may not be representative of historical selection pressures due to reductions in predator abundance from overfishing, the consequences of such reductions in predation intensity have been documented in both temperate and tropical habitats (Carpenter 1984; Hay 1984; Witman and Sebens 1992). Thus, while overfishing may have reduced the absolute level of predation on crabs, the latitudinal gradient in predation pressure has probably existed historically and could have contributed to the geographic differences in crab behavior. This seems particularly likely given the correspondence between latitudinal gradients in predation pressure and the prevalence of prey defenses in other species (Bertness et al. 1981; Coley and Aide 1990; Bolser and Hay 1996).

In addition to latitudinal differences in the overall intensity of predation by fishes, predation pressure changes

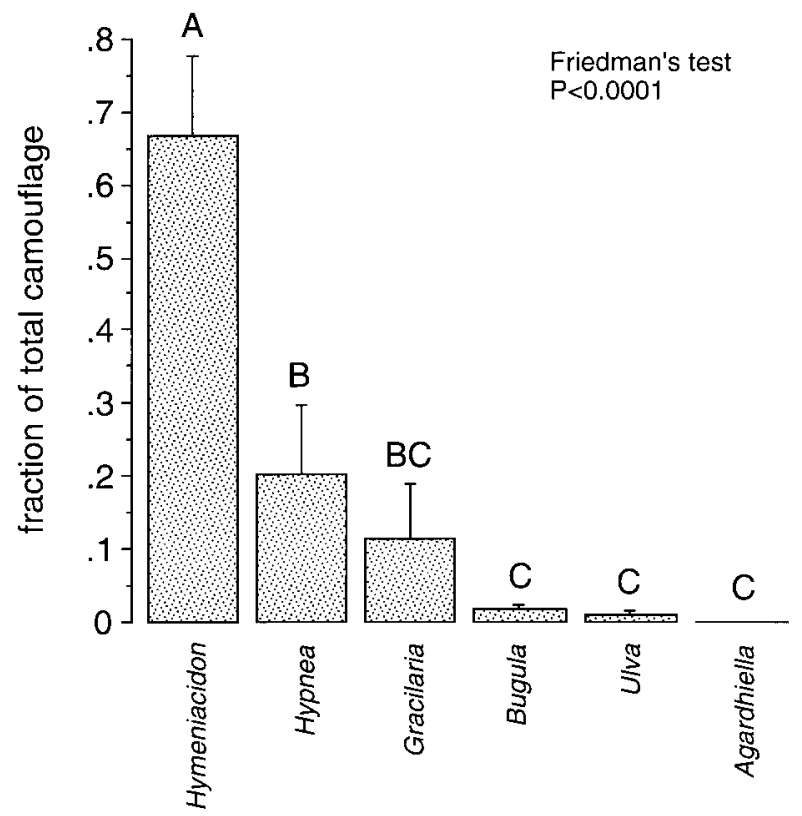

Figure 5: Laboratory decoration choices of Libinia dubia among potential items available in the late spring, before Dictyota became apparent in these habitats. Statistics and symbols are as in figure 2. 


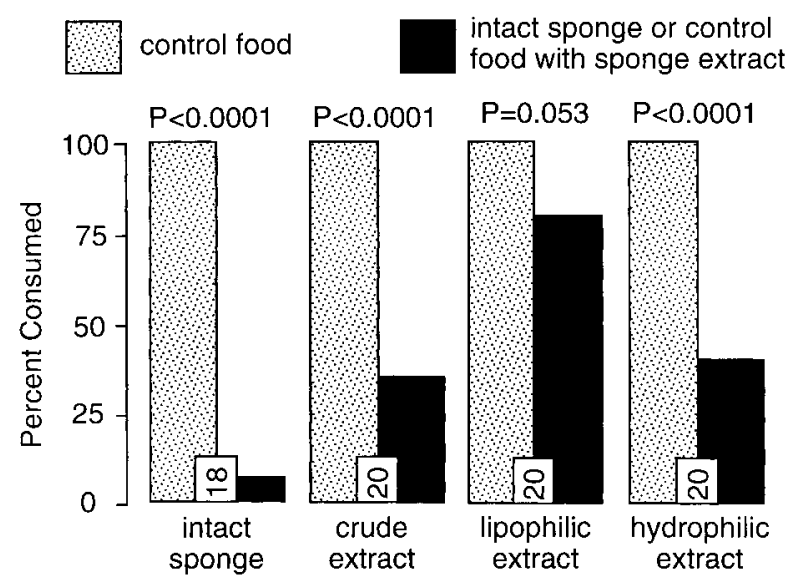

Figure 6: Palatability of the intact sponge and of chemical extracts of the sun sponge Hymeniacidon heliophila to the pinfish Lagodon rhomboides. Statistical analysis was by Fisher's exact test. Sample size $(N)$ is given at the base of each pair of bars.

qualitatively with latitude, as the abundance of herbivorous and omnivorous fishes declines in higher-latitude waters (Horn 1989; Ebeling and Hixon 1991). Fishes that consume both seaweeds and mobile invertebrates (including pinfish [Lagodon rhomboides], sheepshead [Archosargus probatocephalus], and spottail pinfish [Diplodus holbrookii]) are abundant in habitats containing Libinia in the southern portion of its range but rare or absent north of Chesapeake Bay (Tatham et al. 1984; Stone et al. 1994). Where these omnivores are common, camouflage that matches the background is ineffective at reducing predation on Libinia because the background is comprised of seaweeds such as Hypnea that are readily consumed by these locally abundant omnivores (Stachowicz and Hay 1999 c). In these habitats, camouflage with a chemically defended seaweed is a much more effective means of reducing predation (Stachowicz and Hay 1999c). Because few (if any) of the fishes in the northern habitats we studied perceive seaweeds as food, camouflage that allows the crab to blend into the background cover of benthic vegetation may be sufficient to reduce detection by predators. Seaweed chemical defenses can be effective against carnivores (e.g., Paul and Van Alstyne 1988; Hay et al. 1990a, $1990 b$ ), but chemical protection from predation may confer little additional benefit in northern habitats if crabs camouflaged to match the algal background are rarely discovered. Thus, the specialist and generalist strategies may each be favored in different parts of Libinia's geographic range.

\section{Population Subdivision in Libinia}

The observed regional differences in crab camouflage strategy may reflect the division of the species into sub- populations. Although classical life-history theory suggests that localized adaptations are likely to be rare in marine organisms like crabs that typically have long-lived pelagic dispersal phases (e.g., Vance 1973; Scheltema 1986), many organisms do not fit this paradigm (see review in Palumbi 1995). Many factors can contribute to reductions in realized dispersal from the potential dispersal predicted from larval life history. Duration of the planktonic phase of marine invertebrates may be much shorter in the field than in the lab (Olson and MacPherson 1987; Prince et al. 1987; Cronin et al. 1995), which, combined with the short larval period of L. dubia in the laboratory (9 d; Sandifer and Van Engel 1971), suggests that realized dispersal of this species could be relatively restricted. In addition, both physical (Bertness and Gaines 1993; Luettich et al. 1999) and behavioral (Cronin and Forward 1986) mechanisms exist that would favor retention of crab larvae in natal estuaries, although it is not known whether these mechanisms operate for L. dubia. Furthermore, longerdistance dispersal across Cape Hatteras, North Carolina, may be inhibited by ocean currents that flow toward the cape from the south and the north before turning offshore. Even if crabs from northern populations dispersed to North Carolina, they would likely suffer greater predation than native crabs because they would not specialize on chemically defended species. In a field tethering experiment in North Carolina, juvenile Libinia decorated with Hypnea, a palatable alga preferred for camouflage by northern crabs in lab assays (fig. 2), were consumed much more frequently than those decorated with $D$. menstrualis (Stachowicz and Hay 1999c). Although crabs could possibly "learn" the specialized behavior, predation would decrease the probability that northern immigrants would survive the learning process and live to sexual maturity in North Carolina relative to residents.

Oceanographic features, reduced larval dispersal, and geographic variation in selection pressure from fishes could all contribute to the observed regional differences in behavior of Libinia, but can the relative importance of these factors be distinguished? We suggest that limited larval dispersal because of a brief larval period and reduced transport between areas north and south of Cape Hatteras allows population differentiation in response to differential predation regimes. Furthermore, specialization may be more likely in southern populations because the warmer temperatures characteristic of these habitats speed larval development (Sandifer and Van Engel 1971), increasing the probability that larvae will become competent to settle when still close to their natal habitat. Although further evidence is required, an analogous situation does exist among acorn barnacles, which show localized adaptations to thermal stresses only in bays where flushing rates are low, promoting retention of larvae in natal estuaries and 
allowing repeated selection for thermal tolerance in adults over generations (Bertness and Gaines 1993). It seems likely that similar repeated selection over generations would be necessary for the specialized decorating preferences of Libinia to evolve.

Differentiation among these possible alternatives for $\mathrm{Li}$ binia will require integrative studies across levels of biological organization. Genetic comparisons among adult populations and between adults and larval stages using molecular markers may offer some insight as to whether significant dispersal of larvae occurs across the Cape Hatteras biogeographic boundary and whether that dispersal results in the establishment of adults. If northern and southern adult crabs are genetically different but the dispersive larval stages are not, larval transport may be sufficient to promote mixing, and behavioral differences among populations could then be attributed largely to differential postsettlement mortality. The potential for postsettlement predation to maintain differences among populations could be assessed by comparing survival of northern and southern crabs decorated as they choose in tethering experiments at each location. Understanding the subdivision of populations such as this will probably require the integration of investigations at levels from genes to behavior to regional oceanography.

\section{Local Specialization in the Sea}

Local specialization for camouflage among the decorator crabs is facilitated by a decoupling of the choice of plants as food and shelter. Crabs place plant "shelter" on their backs as camouflage but need not use these plants as food. For example, Libinia in North Carolina uses Dictyota for camouflage but avoids consuming this alga (figs. 2, 3). Similarly, other small marine invertebrates exploit plants or sessile animals as refuges from predation but avoid using their host for food (Coen 1988; Duffy 1990, 1993; Hacker and Madin 1990; Stachowicz and Hay 1996, 1999a, $1999 c$; Sotka et al. 1999). In contrast, small terrestrial herbivores, like insects, are most often specialized and use the same plant for food and shelter (Strong et al. 1984). Thus, host shifts to avoid competition or predation may involve a trade-off of decreased growth and survival due to poor metabolic adaptation to the new host (e.g., Feder 1995; Abrahamson and Weis 1997). Such trade-offs are absent when the host is not used for food. Host-switching thus carries relatively little cost for many marine invertebrates, suggesting that local specialization could be an important means of coexisting with local predators in the marine environment. When these host-switches involve genetic or behavioral adaptations to better exploit the new host they may be an important means of generating variability and possibly race formation. Adaptation to local hosts may thus play an evolutionarily important role by facilitating the development, maintenance, and diversification of the growing number of sibling species complexes found in the sea (Buss and Yund 1989; Duffy 1996).

\section{Acknowledgments}

Primary support was provided by the National Science Foundation through grant OCE 95-29784 to M.E.H. and a doctoral fellowship to J.J.S. Additional support came from the University of Connecticut Marine Sciences Institute and from the Harry and Linda Teasley endowment to the Georgia Institute of Technology. J.J.S. was also supported by a fellowship from the Graduate School of the University of North Carolina at Chapel Hill during the initial stages of the investigation. K. Heck, A. Lohrer, and S. O'Brien suggested field sites and/or helped collect crabs in Alabama, Rhode Island, and New Jersey, respectively. Previous drafts of the manuscript benefited from discussions with R. Denno and S. Palumbi and from comments by C. Peterson, S. Gaines, and two anonymous reviewers.

\section{Literature Cited}

Abrahamson, W. G., and A. E. Weis. 1997. Evolutionary ecology across three trophic levels: goldenrods, gallmakers, and natural enemies. Monographs in population biology 29. Princeton University Press, Princeton, N.J.

Abrahamson, W. G., J. F. Sattler, K. D. McCrea, and A. E. Weis. 1989. Variation in selection pressures on the goldenrod gall fly and the competitive interactions of its natural enemies. Oecologia (Berlin) 79:15-22.

Avise, J. C. 1992. Molecular population structure and the biogeographic history of a regional fauna: a case history with lessons for conservation biology. Oikos 63:62-76.

Bertness, M. D., and R. M. Callaway. 1994. Positive interactions in communities: a post Cold War perspective. Trends in Ecology \& Evolution 9:191-193.

Bertness, M. D., and S. D. Gaines. 1993. Larval dispersal and local adaptation in acorn barnacles. Evolution 47: 316-320.

Bertness, M. D., and G. H. Leonard. 1997. The role of positive interactions in communities: lessons from intertidal environments. Ecology 78:1976-1989.

Bertness, M. D., S. D. Garrity, and S. C. Levings. 1981. Predation pressure and gastropod foraging: a tropicaltemperate comparison. Evolution 35:995-1007.

Bolser, R. C., and M. E. Hay. 1996. Are tropical plants better defended? palatability and defenses of temperate vs. tropical seaweeds. Ecology 77:2269-2286.

Boucher, D. H., S. James, and K. H. Keeler. 1982. The ecology of mutualism. Annual Review of Ecology and Systematics 13:315-347. 
Bronstein, J. L. 1994. Our current understanding of mutualism. Quarterly Review of Biology 69:31-51.

Buss, L. W., and P. O. Yund. 1989. A sibling species group of Hydractinia in the north-eastern United States. Journal of the Marine Biological Association of the United Kingdom 69:857-874.

Carpenter, R. C. 1984. Predator and population density control homing behavior in the Caribbean echinoid Diadema antillarum. Marine Biology (Berlin) 82: 101-108.

Coen, L. D. 1988. Herbivory by crabs and the control of algal epibionts on Caribbean host corals. Oecologia (Berlin) 75:198-203.

Coley, P. D., and T. M. Aide. 1990. Comparison of herbivory and plant defenses in temperate and tropical broad-leaved forests. Pages 25-49 in P. W. Price, T. M. Lewinsotin, G. W. Fernandes, and W. W. Benson, eds. Plant-animal interactions: evolutionary ecology in tropical and temperate regions. Wiley, New York.

Cronin, G. C., and M. E. Hay. 1996. Susceptibility to herbivores depends on recent history of both the plant and animal. Ecology 77:1531-1543.

Cronin, G. C., M. E. Hay, W. Fenical, and N. Lindquist. 1995. Distribution, density, and sequestration of host chemical defenses by the specialist nudibranch Tritonia hamnerorum found at high densities on the sea fan Gorgonia ventalina. Marine Ecology Progress Series 119: 177-189.

Cronin, T. W., and R. B. Forward. 1986. Vertical migration cycles of crab larvae and their role in larval dispersal. Bulletin of Marine Science 39:192-201.

Duffy, J. E. 1990. Amphipods on seaweeds: partners or pests? Oecologia (Berlin) 83:267-276.

. 1993. Genetic population structure in two tropical sponge-dwelling shrimps that differ in dispersal potential. Marine Biology (Berlin) 116:459-470.

. 1996. Resource-associated population subdivision in a symbiotic coral-reef shrimp. Evolution 50:360-373.

Ebeling, A. W., and M. A. Hixon. 1991. Tropical and temperate reef fishes: a comparison of community structures. Pages 509-563 in P. F. Sale, ed. The ecology of fishes on coral reefs. Academic Press, San Diego, Calif.

Feder, J. L. 1995. The effects of parasitoids on sympatric host races of Rhagoletis pomonella (Diptera: Tephritidae). Ecology 76:801-813.

Glynn, P. W. 1987. Some ecological consequences of coralcrustacean guard mutualisms in the Indian and Pacific Oceans. Symbiosis 4:301-324.

Hacker, S. D., and L. P. Madin. 1990. Why habitat architecture and color are important to shrimps living in pelagic Sargassum: use of camouflage and plant-part mimicry. Marine Ecology Progress Series 70:143-155.

Hay, M. E. 1984. Patterns of fish and urchin grazing on
Caribbean coral reefs: are previous results typical? Ecology 65:446-454.

- 1986. Associational plant defenses and the maintenance of species diversity: turning competitors into accomplices. American Naturalist 128:617-641.

Hay, M. E., J. E. Duffy, C. A. Pfister, and W. Fenical. 1987. Chemical defense against different marine herbivores: are amphipods insect equivalents? Ecology 68: 1567-1580.

Hay, M. E., P. E. Renaud, and W. Fenical. 1988. Large mobile versus small sedentary herbivores and their resistance to seaweed chemical defenses. Oecologia (Berlin) 75:246-252.

Hay, M. E., J. E. Duffy, and W. Fenical. 1990a. Host-plant specialization decreases predation on a marine amphipod: an herbivore in plant's clothing. Ecology 71: 733-743.

Hay, M. E., J. E. Duffy, V. J. Paul, P. E. Renaud, and W. Fenical. 1990b. Specialist herbivores reduce their susceptibility to predation by feeding on the chemically defended seaweed Avrainvillea longicaulis. Limnology and Oceanography 35:1734-1743.

Heck, K. L., Jr., and K. A. Wilson. 1987. Predation rates on decapod crustaceans in latitudinally separated seagrass communities: a study of spatial and temporal variation using tethering techniques. Journal of Experimental Marine Biology and Ecology 107:87-100.

Holzapfel, C., and B. E. Mahall. 1999. Bi-directional facilitation and interference between shrubs and annuals in the Mojave desert. Ecology 80:1747-1761.

Horn, M. H. 1989. Biology of marine herbivorous fishes. Oceanography and Marine Biology Annual Review 27: 167-272.

Jablonski, D. 1986. Larval ecology and macroevolution in marine invertebrates. Bulletin of Marine Science 39: 565-587.

Janzen, D. H. 1973. Dissolution of mutualism between Cecropia and its Azteca ants. Biotropica 5:15-28.

Kareiva P. M., and M. D. Bertness. 1997. Re-examining the role of positive interactions in communities. Ecology 78:1945.

Kilar, J. A., and R. M. Lou. 1986. The subtleties of camouflage and dietary preference of the decorator crab, Microphyrs bicornutus Latreille (Decapoda: Brachyura). Journal of Experimental Marine Biology and Ecology 101:143-160.

Littler, M. M., D. S. Littler, and P. R. Taylor. 1995. Selective herbivore increases the biomass of its prey: a chitoncoralline reef building association. Ecology 76: 1666-1681.

Luettich, R. A., J. L. Hench, C. W. Fulcher, F. E. Werner, B. O. Blanton, and J. H. Churchill. 1999. Barotropic tidal and wind-driven larval transport in the vicinity of 
a barrier island inlet. Fisheries Oceanography 8(suppl. 2):190-209.

Menge, B. A., and J. Lubchenco. 1981. Community organization in temperate and tropical rocky intertidal habitats: prey refuges in relation to consumer pressure gradients. Ecological Monographs 51:429-450.

Olson, R. R., and R. MacPherson. 1987. Potential vs. realized dispersal: fish predation on larvae of the ascidian Lissoclinum patella (Gottschaldt). Journal of Experimental Marine Biology and Ecology 110:245-256.

Palumbi, S. R. 1985. Spatial variation in an alga-sponge commensalism and the evolution of ecological interactions. American Naturalist 126:267-274.

- 1992. Marine speciation on a small planet. Trends in Ecology \& Evolution 7:114-118.

- 1995. Using genetics as an indirect estimator of larval dispersal. Pages 369-387 in L. McEdward, ed. Ecology of marine invertebrate larvae. CRC, Boca Raton, Fla.

Paul, V. J., and K. L. Van Alstyne. 1988. Use of ingested algal diterpenoids by Elysia halimedae Macnae (Opisthobranchia: Ascoglossa) as anti-predator defenses. Journal of Experimental Marine Biology and Ecology 119:15-29.

Pennings, S. C. 1990. Multiple factors promoting narrow host range in the sea hare, Aplysia californica. Oecologia (Berlin) 82:192-200.

Prince, J. D., T. L. Sellers, W. B. Ford, and S. R. Talbot. 1987. Experimental evidence for limited dispersal of haliotid larvae (genus Haliotis; Mollusca: Gastropoda). Journal of Experimental Marine Biology and Ecology 106:243-263.

Renaud, P. E., M. E. Hay, and T. M. Schmitt. 1990. Interactions of plants stress and herbivory: intraspecific variation in the susceptibility of a palatable versus an unpalatable seaweed to sea urchin grazing. Oecologia (Berlin) 82:217-226.

Richardson, J. P. 1979. Overwintering of Dictyota dichotoma (Phaeophyceae) near its northern distribution limit on the east coast of North America. Journal of Phycology 15:22-26.

Rickson, F. R. 1977. Progressive loss of ant-related traits of Cecropia peltata on selected Caribbean Islands. American Journal of Botany 64:585-592.

Sandifer, P. A., and W. A. Van Engel. 1971. Larval development of the spider crab Libinia dubia (Brachyura, Majidae, Pisinae) reared in laboratory culture. Chesapeake Science 12:18-25.

Scheltema, R. S. 1986. On dispersal and planktonic larvae of benthic invertebrates: an eclectic overview and summary of problems. Bulletin of Marine Science 39: 290-322.

Schneider, C. W., and R. B. Searles. 1991. Seaweeds of the southeastern United States. Duke University Press, Durham, N.C.

Sotka, E. E., M. E. Hay, and J. D. Thomas. 1999. Hostplant specialization by a non-herbivorous amphipod: advantages for the amphipod and costs for the seaweed. Oecologia (Berlin) 118:471-482.

Stachowicz, J. J., and M. E. Hay. 1996. Facultative mutualism between an herbivorous crab and a coralline alga: advantages of eating noxious seaweeds. Oecologia (Berlin) 105:377-387.

. 1999a. Mutualism and coral persistence: the role of herbivore resistance to algal chemical defense. Ecology 80:2085-2101.

- 1999b. Reduced mobility is associated with compensatory feeding and increased diet breadth of marine crabs. Marine Ecology Progress Series 188:169-178.

- 1999c. Reducing predation through chemicallymediated camouflage: indirect effects of plant defenses on herbivores. Ecology 80:495-509.

Stachowicz, J. J., and N. Lindquist. 1997. Chemical defense among hydroids on pelagic Sargassum: predator deterrence and absorption of solar UV radiation by secondary metabolites. Marine Ecology Progress Series 155: 115-126.

Steiner, K. E., and V. B. Whitehead. 1990. Pollinator adaptation to oil-secreting flowers-Rediviva and Diascia. Evolution 44:1701-1707.

Steneck, R. S. 1982. A limpet-coralline alga association: adaptations and defenses between a selective herbivore and its prey. Ecology 63:507-522.

Stone, S. L., T. A. Lowery, J. D. Field, C. D. Williams, D. M. Nelson, S. H. Jury, M. E. Monaco, and L. Andreason. 1994. Distribution and abundance of fishes and invertebrates in Mid-Atlantic estuaries. Report 12. Strategic Environmental Assessments Division, Silver Spring, Md.

Strong, D. R., J. H. Lawton, and R. Southwood. 1984. Insects on plants. Harvard University Press, Cambridge, Mass.

Tatham, T. R., D. L. Thomas, and D. J. Danila. 1984. Fishes of Barnegat Bay. Pages 241-280 in M. J. Kennish and R. A. Lutz, eds. Ecology of Barnegat Bay, New Jersey. Springer, New York.

Tauber, C. A., M. J. Tauber, and L. R. Milbrath. 1995. Individual repeatability and geographical variation in the larval behavior of the generalist predator, Chrysopa quadripunctata. Animal Behaviour 50:1391-1403.

Thompson, J. N. 1994. The coevolutionary process. University of Chicago Press, Chicago.

Travis, J. 1996. The significance of geographical variation in species interactions. American Naturalist 148(suppl.): S1-S8. 
Vance, R. R. 1973. On reproductive strategies in marine invertebrates. American Naturalist 107:339-352.

Whitham, T. G. 1983. Host manipulation of parasites: within-plant variation as a defense against rapidly evolving pests. Pages 15-41 in R. F. Denno and M. S. McClure, eds. Variable plants and herbivores in natural and managed systems. Academic Press, New York.
Williams, A. B. 1984. Shrimps, lobsters and crabs of the Atlantic coast. Smithsonian, Washington, D.C.

Witman, J. D., and K. P. Sebens. 1992. Regional variation in fish predation intensity: a historical perspective in the Gulf of Maine. Oecologia (Berlin) 90:305-315.

Associate Editor: Steven D. Gaines 